\title{
デジタルサイネージの動向
}

\section{The trend of digital signage}

\section{中村 伊知哉 ${ }^{1}$}

\section{NAKAMURA Ichiya ${ }^{1}$}

1 慶應義塾大学大学院メディアデザイン研究科（†107-0052 東京都港区赤坂3-13-3-4F） E-mail : ichiya@aol.com

1 Graduate School of Media Design, KEIO University (3-13-3-4F Akasaka Minato-ku, Tokyo 107-0052)

原稿受理 $(2012-12-28)$

情報管理 55(12), 891-898, doi: 10.1241/johokanri.55.891 (http://dx.doi.org/10.1241/johokanri.55.891)

\section{著者抄録}

デジタルサイネージは，かつて電子看板と呼ばれていたが，屋内でも，小型の画面でも使われ，広告以外の多様な情 報も発信されるようになり，新しいメディアとして発展が期待されている。最近の動向としては，(1)パーソナル：家 庭にも普及を始めている，(2)パブリック：学校，病院，役所などで公共的な情報の共有手段になりつつある，(3)ポッ プ: 目を引く楽しいコンテンツが増加している，の3点が挙げられる。さらに，(1)べんり＝役立つメディアへの進化， (2)つながる＝ネットワーク化，(3)みんな=ソーシャルメディアとの連動，という傾向を強めるとともに，自動販売機， ケータイ，カラオケなど日本が強みを持つ機器・ビジネスとの連動も目立っている。

キーワード

デジタルサイネージ，電子看板，ディスプレイ，ネットワーク，コンテンツ，情報共有，パブリック，ソーシャルメディア

\section{1.はじめに}

駅前ビルの壁にある巨大なディスプレイに広告が 流れている。デパートの入り口，タテ型の薄い液晶 画面では催しもののお知らせ。電車の中では，次の 停車駅を案内する画面のとなりの画面で，クイズ映 像が放映されている。商店街の居酒屋の前では本日 のスペシャリティが表示されている。

街のあちこちで，大小のディスプレイを用いたさ まざまな映像が目につくようになった。気がつけば さまざまなディスプレイが屋外にも屋内にも埋め込 まれていて，いや応なく映像が視界に飛び込んでく る。
こうした新しいメディアを総称する言葉が「デジ タルサイネージ」だ。本稿では，デジタルサイネー ジの現状と発展動向について俯瞰するとともに，日 本の特性を活かした進展の可能性を述べる。

2.デジタルサイネージとは

\section{1 デジタルサイネージの来歴と現在}

デジタルサイネージは，現在，成長産業として注 目を集めている。広告・マーケティング業界，家電 業界，通信業界などが，この分野を新しい有望ジャ ンルとしてとらえている。

それは，従来のテレビや新聞とは異なる，時間と 
場所を特定したメディアだからである。インターネッ トやケータイとも異なり，街や店舗で接するメディ ア。新しい広告メディア, 新しいマーケティング手法, 新しいデジタル産業，そして新しい文化として期待 されているのだ。

この新メディアを発展させるため，2007年に「デ ジタルサイネージコンソーシアム」を結成した。そ のころには，電子看板，アウトオブホームメディア， 電子ポスター，デジタルポップなど，さまざまな呼 び方があったが, 現在ではほぼ「デジタルサイネージ」 というぼんやりした呼称に統一された。看板ではな い非広告タイプのものも多く，屋外ばかりでなく屋 内のディスプレイも多く存在する。まだ概念が固ま らないぼんやりしたメディアなのだ。だが，急速に その利用範囲を拡大している。

\section{2 デジタルサイネージの典型例}

(1) JR渋谷駅ハチ公前の大型ビジョン

デジタルサイネージの典型例は，都会の真ん中に あるビルに設置されている大型ビジョンである。JR 渋谷駅ハチ公前に4機並ぶ大型ビジョンでは，待ち 合わせ中の学生や交差点を横断する人々が，新発売 のCDの情報や星座占いといったコンテンツを見てい る。1日平均30万人が通行するという。

(2) 東京ミッドタウン

3つのゾーンに分かれる施設内に大小合わせて150 枚のディスプレイが並べられている。画面にはイベ ント告知，施設案内，アート情報，天気予報，二ュー スが流れている。タッチパネル式のものも多く，場 所柄コンテンツも外国語対応になっている。

(3) 六本木ヒルズ

2003年オープンの円形の建物「メトロハット」で は，さまざまなデジタルサイネージが活用されてい る。壁面には500インチのLED（発光ダイオード）ア ストロウォール，内側には200インチのLEDアストロ ビジョンが据えられている。このほか，プラズマ， 液晶など300台のディスプレイが据えられており，光



図1東京ミッドタウンの館内案内サイネージ

LANで結ばれている。

(4) 丸の内

丸の内には76台のサイネージが設置されている。 そして，これらがネットワークのシステムとしてつ ながっている。いつどの面にどんな情報を流すかが コントロールされている。また同様のサイネージ64 台が赤坂サカスにも設置されている。

(5) 電車の中の液晶モニター

電車で通勤・通学する人にとつて最も身近なデジ タルサイネージは，電車の中の液晶モニターであろ う。JR東日本の「トレインチャンネル」，JR西日本の 「WESTビジョン」などがその代表例だ。次の駅まで3 分といった運行情報もあれば，一般企業のコマーシャ ル，天気予報や二ュース，英会話のミニレッスンな ども放映されている。トレインチャンネルは平日平 均1,000万人が接する人気メディアで，テレビを上回 る広告効果を上げているという11,2)。

（6）集積度を誇るJR大阪駅

2011年5月にリニューアルオープンしたJR大阪駅 では，350面を超えるデジタルサイネージが整備され た。206インチ相当のマルチディスプレイや，12面を 横一列にし，幅 9 メートルの大きさで，インパクトが あるものが設置された。集積度は日本でも最大級と される。 
(7) 店頭の小さいサイネージ

スーパーや薬局の棚には小さいサイネージがたく さん置かれている。薬局のマツモトキヨシでは化粧 品売り場に小型ディスプレイを設置しCMを流してい る。イトーヨーカドーの食品売り場ではケータイぐ らいの大きさのディスプレイでヨーグルトの商品案 内をしている。

\section{3 どこにでも入り込めるサイネージ}

このようにデジタルサイネージは配置される場所 もさまざまだ。具体的には電車やバスの車内，駅ナ 力や商店街，学校・病院・役所といった公共施設， ライブハウス，スタジアム，イベント会場。自動販 売機，公衆電話，公衆トイレ，オフィスビル。屋外 でも屋内でも，商業施設でも公共空間でも，パブリッ クでオープンな場所でもプライベートな密室でもど こでもサイネージのテリトリーになりうる。大きな 画面も小さな画面も，入り込む余地がある。

銀行の看板，学校の掲示板，電車の中吊りなどは， どれも大きなサイネージになりうる。スーパーの值 札，宝くじ売り場の売り出し情報，マンションの表 札は，どれも小さな画面のサイネージになりうる。 そして，それらのすべてがネットワークで結ばれる。

\section{4 ユビキタス社会を実現する手段}

「いつでも，どこでも，だれとでも」という情報社 会の発展像を描く「ユビキタス」注1) という言葉があ る。時間，場所，相手を問わずコミュニケーション ができるという意味だ。

サイネージはまさにこの「ユビキタス」社会を実 現する手段なのである。外でも屋内でも，あちこちで， 大衆向けのテレビと，個人向けのケータイの両方の 特徵を併せ持ち，間に立って情報をつなぐ。

ただし，サイネージは，「いまだけ，ここだけ，あ なただけ」に伝えるメディアであり，明確な目的を もち効果を伴って情報を送り届ける手段なのである。

\section{5 デジタルサイネージの概念}

デジタルサイネージの概念は広い。デジタルサイ ネージコンソーシアムによれば，デジタルサイネー ジの定義は，「屋外・店頭・公共空間・交通機関など， あらゆる場所で，ネットワークに接続したディスプ レイなどの電子的な表示機器を使って情報を発信す るシステム」とされる。

つまり，電子看板にイメージを代表される「屋外 の大型画面による広告」にとどまるものではない。 屋内でも，小型の表示システムでも，広告以外のコ ンテンツでも，さまざまな情報がデジタルでつながっ て流れる。そうしたトータルな環境を称する概念な のだ。

既に，ホテルのコンシェルジュのような案内＆相 談ツール，駅や空港での運行情報の掲示板としても 使用されている。株価情報を金融機関の店内で表示 したり，食品の値段をスーパーの画面で知らせたり している。また，壁，地面，噴水をサイネージ化して， 街をメディア化していく試みもなされている。都市 景観や風景を向上させたり，アートとして地域の価 值を上げたりすることにも活用される。今後は，ビ ルのオーナーやデベロッパーが土地や建物の価值を 上げるためにデジタルサイネージを取り入れていく ことも考えられる。

\section{6 デジタルサイネージをとりまく技術開発}

技術開発も進んでいる。まず，映像ディスプレイ の開発である。さまざまな大きさや形態の映像ディ スプレイが開発されることで，今までにはなかった 場所に新しい広告需要が生まれる。薄さ $3 \mathrm{~m} m$ という ディスプレイも登場し，これまで物理的に映像ディ スプレイを置くことが難しかった場所にも設置でき るようになっている。

もう1つは音声に関する開発である。指向性の高 いスピーカーを開発し，通行する人にピンポイント でささやく「音のサイネージ」も導入されている。 ヤマハは，布や紙のように薄くて曲げられるスピー 
カーを開発し，駅を通過する人に催し物を案内した り，モーターショーでエンジン音を聞かせたりする といった利用が進んでいる。ポスターはあるが，ど こから音が出ているのだろう，という驚きがその場 にいる人の注意を惹きつける。

さらに今後は，五感に訴える楽しく臨場感のある 情報表示屯追求される。聴覚，触覚，嗅覚，味覚。 触るサイネージも登場する。NTTコミュニケーショ ンズでは，映像と連動した「香り」を発生させて嗅 覚に訴える「香りサイネージ」も開発している。

\section{3. 最近の発展動向}

\subsection{3つのP : Personal, Public, Pop}

ここ数年，サイネージは大きな変化を遂げている。 それを象徵するのが3つの「P」, Personal, Public, Popである。

(1) Personal（パーソナル）

モールや高級ブティック，金融機関などのハイエ ンドから，鉄道，商業施設などのミドルエンド，そ して個人商店や一般オフィスなどのローエンドへと 普及が進んできたサイネージ。屋外の大型ディスプ レイから屋内の小型ディスプレイまでをカバーする 広がりを見せている。

それが今度は一足飛びに家庭の中にも進出し始め

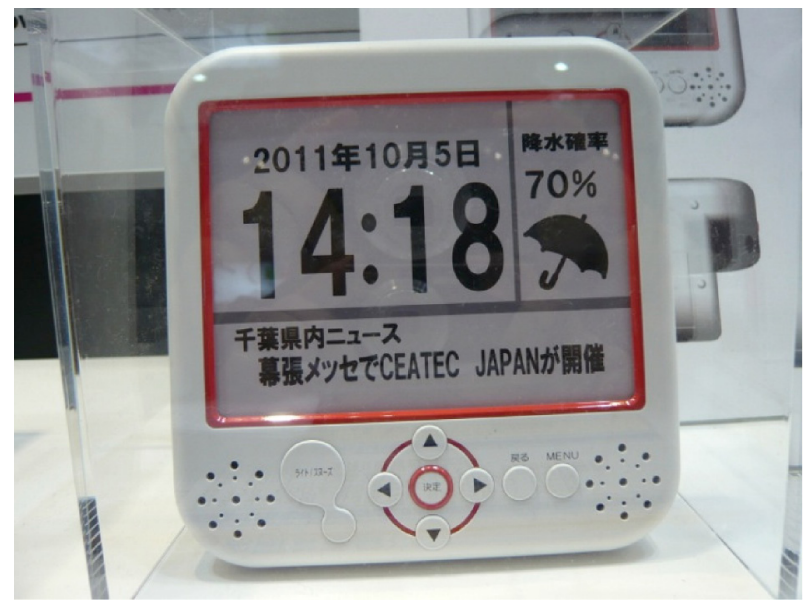

図2 エフエム東京開発の家庭内小型サイネージ
た。フォトフレームやタブレットPCをブロードバン ド・インターネットにつなぎ，茶の間に情報を届け るサイネージが商用化されている。テレビ，PC，ケー タイとは別の「第4のメディア」が家の中にも居場所 を見つけて，24時間スイッチオンという，テレビ， $P C$ ，ケータイとは異なる機能を発揮しようとしてい る。光ファイバーが浸透している日本が世界に先行 する形でサービスを開発している。

放送の電波も使われる。エフエム東京では，地デ ジの電波に情報を重畳させて，家庭内の小型サイネ一 ジ端末に緊急情報を送るシステムを開発している。

(2) Public（パブリック）

サイネージは当初は広告メディアだと目されてい た。しかし昨今では広告媒体として使われるだけで はない。電車での運行情報，銀行での金利情報，ホ テル入りロでの催し案内などはCMではなく来場者へ の情報サービスの提供手段として使用されている。 一般のオフィスでも，職員の情報共有のためにサイ ネージが活用されつつある。

特に近年は，学校，病院，役所でも急速に利用が 広がっている。授業の情報や就職案内をディスプレ イ表示する大学。診察室への誘導，支払いや投薬の 情報を画面で表示する病院。街路の画面で防災情報 を流す自治体などが現れ始めている。「みんなで見る」 サイネージはパブリックな利用から先行的に広がっ ていく可能性も十分にある。

現在，広がりをみせる学校や病院のサイネージを 形成するハードウェアやネットワークの原資は，広 告費ではなく，学費や医療費である。日本はこれら パブリックな分野の情報化が遅れているが，教育・ 医療コスト計 50 兆円の $1 \%$ \%゙デジタル化投資に向けら れれば, それだけで一産業となる。

(3) Pop（ポップ）

ポップカルチャーの国，日本ならではのモデルも 現実化してきた。アニメやゲームのキャラクターを 登場させた目を引くコンテンツがその特徴である。 ゲーム機やカラオケ，パチンコと連動したサイネー 
ジは，海外ではあまり見られないギャグ風の仕組み をもつ遊び心をもつサイネージである。これは楽し く発展する可能性がある。

\section{2 新たなトレンド : ベんり，つながる，みんな}

そして，2011年3月11日に発生した東日本大震災 を機に，デジタルサイネージ業界は，あらためて自 分自身を見つ直すことになつた。東京電力福島第 一原子力発電所の事故による節電の要請や自肃ム一 ドで灯火の消える都会。そんな中でサイネージはど う身をこなせばよいのか業界は悩み，考え，議論を 重ねた。

当時，首都圏では一斉にスイッチを落としたサイ ネージも，世間が平静を取り戻すにつれ，徐々に点 灯していった。被災地および全国で必要な情報を届 けられるよう努めた。平時でも災害時でも社会の役 に立つメディアへ成長したいと考えたのである。

そこで，2011年以降，日本のサイネージには，ま たも新たなトレンドが重畳した。「べんりつつながる 十みんな」の3傾向である。

(1)べんり=役立つ

国民，ユーザーの役に立つメディアになりたい。 街のあちこちで災害情報や電力消費状況を表示した り，学校や病院でも公的な情報を発信したりしてい る。エンターティンメントから，働くメディアへの 拡張だ。震災直後には，報道番組で埋められたテレ ビが止められることはなかった。デジタルサイネー ジは電力節約に協力して消灯されたが，これに対す る反省である。そして現在，地方自治体は，デジタ ルサイネージの情報発信機能に注目している。町の どこにいても緊急の情報を届けることができるメ ディアが求められているためである。

(2) つながるニネットワーク

ネットワークでつながっていなければメディアで はない。従来は孤立した看板型が多かったのだが， 近年ではブロードバンドや地デジとつながって，街 を面的に覆うシステムになっている。オフィスや家

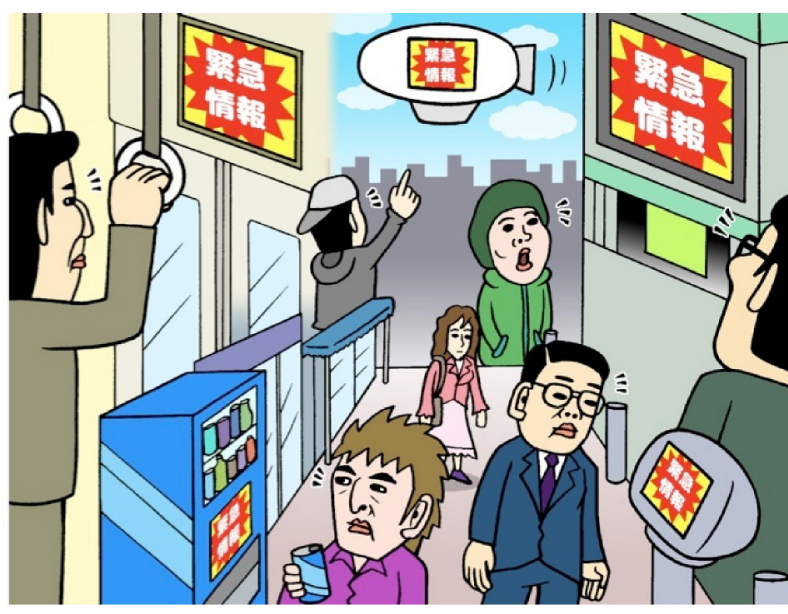

図3街中の緊急情報サイネージのイメージ図（画：ピヨコタン）

の中もマルチデバイスが連結する。

(3) みんな＝ソーシャル

Twitter, mixi，Facebookなどのソーシャルネット ワーキングサービスと連携したり，誰もが簡単にコ ンテンツが作れたりするメディアへ進化する。プロ が作るコンテンツから，みんなで作るコンテンツへ の展開だ。タッチパネル式のデジタルサイネージも 急増。見るだけの片方向メディアから，双方向に「参 加する」メディアへと変身しつつある。

\section{3 新たなトレンドへの対応}

こうした新しいトレンドへの日本企業の対応は早 い。東日本大震災から3か月後の2011年6月に開催さ れた展示会「デジタルサイネージジャパン2011」で も，早くもその対応を明確に見ることができた。

役立つ系では，大日本印刷や凸版印刷などが大学， 病院，行政，オフィス向けのサイネージを提案し， PDC社は災害時にも働く太陽電池のサイネージを展 示した。

つながる系では，家庭内を対象とするNTTの「ひ かりサイネージ」や，日立製作所の「クラウドサイネー ジ」など，サイネージがインターネットメディアで あることが鮮明に示された。地デジの電波で配信す るモデルも複数見られた。

みんな系では，Twitter災害情報の表示システムな 
ど、ソーシャルメディアと連動したモデルやサイネー ジ向けコンテンツ制作ツールなどが提案されていた。

この傾向は2012年以降も变わらず，「役に立つ，参 加型のネットワークメディア」へと進展している。

\section{4. 日本型モデル}

4.1 日本の強み : ネットワーク，ディスプレイ， コンテンツ

デジタルサイネージは欧米先行型で普及してきた が，日本には，欧米にない多くの持ち物がある。そ れは光ファイバーなど世界最先端のデジタルネット ワークである。モバイルや自販機と連動してビジネ スを広げられる可能性も大きい。また，薄型ディス プレイの製造力も残る。そして，ポップで愉快で軽 快なコンテンツを制作するカもトップクラスである。

このように，日本はネットワーク，ディスプレイ， コンテンツの3つを自国内で生産・調達できる数少な い国なのだ。「日本のサイネージは世界トップ」と評 価する声も多い3)。

筆者は世界50を超える都市のデジタルサイネージ を見て回っているが，もはや欧米だけでなく，アジ ア各国でも多数のディスプレイが面的に敷き詰めら れ，それらがネットワークでつながって表示される システムは当たり前になってきた。つい先日，北京 を訪れた際にも，空港内に大型のLEDや液晶ディスプ レイが何面も敷き詰められて観光案内を流しており， 天安門広場では巨大なLED画面が2基，国威発揚映像 を放映していた。つい数年前にはなかった光景だ。 世界の至るところで増殖している。

そのような中でも日本のデジタルサイネージは高 度で，スマートで，ポップな進化を遂げている。強 いてライバルを挙げれば, 韓国であろう。韓国もまた， ブロードバンド, ディスプレイ,コンテンツの3点セッ トを併せ持つ。

韓国も日本に遅れること5年，2012年に政府の支 援のもとで業界団体「テレスクリーン協会」を設立，
活動を始めた。われわれ日本のデジタルサイネージ コンソーシアムとも対話をしている。アジアがこの 分野を牽引することを互いに期待している。

\section{2 日本の発展シナリオ}

デジタルサイネージには，日本ならではの発展シ ナリオがあり得る。

例えば，その一例として自動販売機が挙げられる。 日本は自販機王国である。国内に600万台が設置され ているという。最近は，その自販機の中に液晶画面 が埋め込まれていて，商品やキャンペーンの情報が 流されるものも多い。24時間，電源オンで，インター ネットでつなぐこともできる。その自販機がサイネー ジ機となっていく。

$J R$ 東日本の駅で展開されているサイネージ自販機 は，全面にジュースなどの商品見本ではなく47イン チのスクリーンがあるだけで，しかもカメラが備え られており，購買者の年齢や性別が判別できるよう になっている。自販機の前に誰もいないときはコン テンツを配信し，人が自販機の前に立って商品を購 入しようとすると，年齢や性別を判定してオススメ 商品を表示する。

自販機以上に期待のかかるのがケータイとの連動 である。モバイル通信を利用するという点では，日 本が世界をリードしている。ケータイコンテンツの

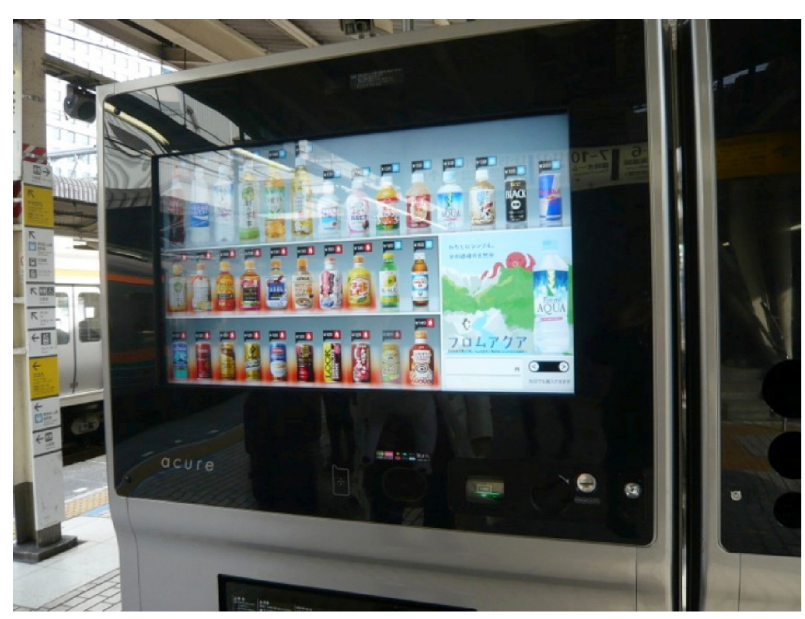

図4 サイネージ自販機 
ビジネスは，日本では「ガラパゴス症候群」と挪揄 されるほど世界にない高機能なシステムが普及して いる。

今後これがサイネージと合体するのだ。マス向け の大型ディスプレイと，個人の手のひらのケータイ 端末とを連動させて情報を流す。ケータイのもつ課 金機能を活かして購買にもつなげる。サイネージ十 ケータイのビジネスがどのように発展するのかが国 際的にも注目されている。

コンビニのデジタルサイネージがケータイにフェ リカをタッチさせているように，大画面で見せて手 のひらに誘導するモデルは定着した。逆に，ケータ イからサイネージに情報を発信するモデルが注目さ れている。

さらに秋葉原のヨドバシカメラ前では，ケータイ を手にしたアベックが巨大ディスプレイに向かって 数字を打ち込むゲームをしている。ケータイから Twitterでサイネージ表示するシステムもある。老若 男女がモバイルで発信する情報リテラシーの高さは， 日本が10年以上の歳月をかけて育ててきたものであ り，今後、スマートフォンが広がる世界市場に向けて， 今のうちにビジネスモデルを構築しておくことが戦 略となる。

\section{3 日本的なサイネージの例}

他にも以下のように日本的なサイネージはたくさ んある。

\section{(1) カラオケ}

客が入っていても3分の1の時間はカラオケに使わ れていないという。歌っていない間のディスプレイ は絶好のCMメディアとなる。

(2) パチンコ

最近のパチンコ台は中央にディスプレイが埋め込 まれていて，アニメや特撮ドラマを題材にしたタイ アップ機や，著名芸能人が監修またはモチーフとす るものもある。

\section{(3) ゲームセンター}

スロットマシンは筐体が動画メディア化してい る。パチスロ「俺の空」や「バーチャファイター」は， 数字やチェリーが回る周囲が皆動画を表示するスク リーンとなって，一体としてエンターテインメント を提供している。

(4) 男子用トイレ

セガは男子用便器の上部にディスプレイを設置し， 用を足すユーザーの尿量でゲームをするという「ト イレッツ」なるサイネージ商品を開発している。隠 れた本音を言い当てる「尿内チェッカー」や，尿量 で対戦する「溜めろ! 小便小僧」など，トイレで遊 ぶふざけたコンテンツばかりなのだが，トイレを遊 びのメディアにするという発想は，斬新なエンター テインメントを作り続けてきた日本ゲーム産業の面 目躍如と言えよう。セガはこれを輸出商品にしたい と目論んでいる。

(5)「ミク」サイネージ

秋葉原駅構内に置かれたディスプレイの前に立つ と，映し出された自分が「初音ミク」に変身させら れてしまう。デジタルサイネージコンソーシアムが 行った実験である。うれしくなって足を止めると，「献 血に行こう」という呼び掛けが表れる。赤十字社と 連携したポップ献血キャンペーンだ。結構な数の献 血が集まったのは，「ミク」サイネージとアキハバラ
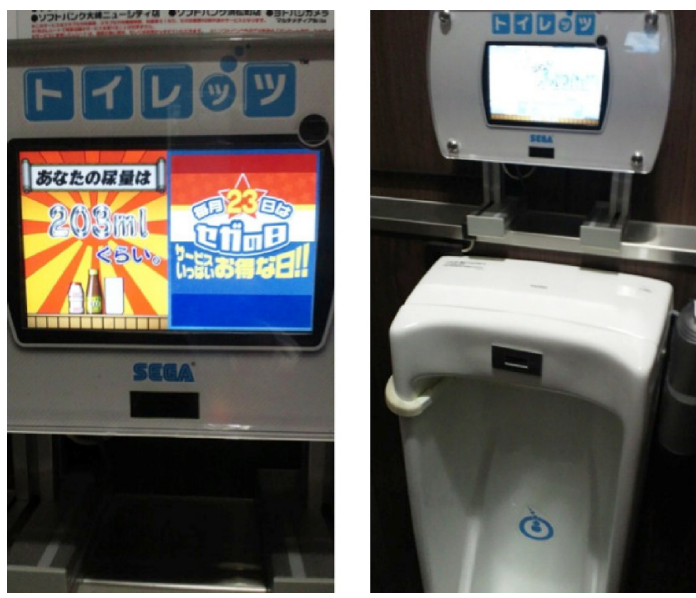

図5 トイレッツ 
の土地柄との相性であろう。

(6) 大阪の「だるまビジョン」

大阪の千日前に「だるま」という店がある。巨大 なヒゲおじさんの立体看板の下にある電子看板「だ るまビジョン」では，浪速のロッキー・赤井英和さ んが「二度づけ禁止！」と訴える。地元民は，おつ 串揚げ屋か，と認識する。大阪の串揚げ店ではソー スの壸が共用で，食べかけたものを二度つけるのは ご法度であることが常識として共有されているから だ。けったいな，でもナルホドとうならせるコテコ テのローカルサイネージである。

\section{5. おわりに}

筆者は内閣官房・知財本部のコンテンツ調査会長
を務めており，日本のコンテンツを世界で展開する 方策を多くの省庁とともに練っている。そのポイン トは，技術力と文化力のドッキングだと考える。

ケータイ，自販機，カラオケ，これら「ものづくり」 の力二技術力と，「ポップなコンテンツ」=文化力の ドッキングが威力を発揮する。世界に打って出るに は，この「ハード」と「ソフト」を合体した力が必 要である。その両方をもっているのが日本の強みな のだ。

ハードとソフトを合体したデジタルサイネージは， その力を発揮できる分野であろう。サービスとビジ ネスを開拓しつつ，世界市場で展開する構図を描い ていきたい。

\section{本文の注}

注1）ユビキタスとは，元は，神々が遍在する，という意味のラテン語で，コンピューターが至るところに あるというイメージで使われているのだが，一神教の欧米より，やおよろずの神々が棲むニッポンの ほうがしっくりくる。

\section{参考文献}

1）中村伊知哉, 石戸奈々子. デジタルサイネージ革命. 朝日新聞出版, 2009, p. 106.

2) 中村伊知哉, 石戸奈々子. デジタルサイネージ戦略. アスキー・メディアワークス, 2010, p. 100.

3）中村伊知哉, 石戸奈々子. デジタルサイネージ革命. 朝日新聞出版, 2009, p. 25, 218.

\section{Author Abstract}

Digital signage, which consists of display, network, and information, is spreading over and expected as a growing market. Three " $P$ " $s$ can be pointed out as trend. 1) Personal: Home digital signage has been developed. 2) Public: Schools, hospitals, governments are now big users. 3) Pop: You can find a lot of enjoyable content. In addition, it is evolving to a more useful media connecting with digital networks and social network services.

\section{Key words}

digital signage, $\mathrm{OOH}$ (Out of Home), display, network, content, information sharing, public, social media 